\title{
魚ロボットまわりの流動の計測および数値解析
}

\section{Measurement and Numerical Analysis of Water Flow around a Fish Robot}

学 O玉地 俊明 (阪市大院) 学 谷中悟史 (阪市大院) 正 高田洋吾 (阪市大) 正 脇坂 知行 (阪市大) Toshiaki TAMACHI, Satoshi TANINAKA, Yogo TAKADA and Tomoyuki WAKISAKA

Graduate School of Engineering, Osaka City University, 3-3-138 Sugimoto, Sumiyosi-ku, Osaka 558-8585

\section{1. 緒 言}

魚の尾びれによる推進は，プロペラによる推進に比べ，最高速 度，加速度，旋回性能など，あらゆる面で優れているとされてお り，今後も益々注目されていくと考えられる，本研究では，魚の 推進メカニズムの解明を目的として, 粒子画像流速測定法 (PIV) による計測と, 数值流体力学 (CFD) による流動解析により, 市 販の魚ロボットまわりの水の流動状態について調べた.

\section{PIVによる計測およびCFD 解析}

PIV による流速測定実験装置の概要図を図 1 左に示す，代表速 度 $U_{m}=148 \mathrm{~mm} / \mathrm{s}$ で流れる回流水槽の観測部中央に市販の魚口ボ ットを固定し，尾びれを動作させた，照明は横方向からシ一ト状 に照射し，観測部下方に設置された撮影装置によって得られた連 続画像の相関から流速を求めた．照明装置には，力トウ光研(株) 製の LD 励起固体レーザ（50 mW）を，撮影装置には，(株)ディ テクト製の高速度 CCD カメラ(毎秒 200 フレーム)をそれぞれ用い た，図 1 右に魚ロボットの寸法およびPIVによる計測範囲（破線 枠内）を示す．また，CFDの手法として，著者らの開発した GTT 法(1)を用いて 2 次元解析を行った. 計算格子は $72 \times 175$ に分割し, 特に魚ロボットまわりでは格子間隔を細かくした。計算格子デー 夕は,事前に高速度カメラにより得た画像をもとに複数個作成し ておき, 計算時間毎に必要な格子点の座標を2つの格子データの 補間により求めた。

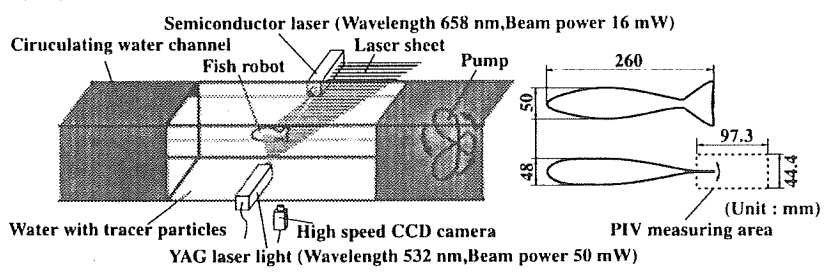

Fig.1 Experimental system and PIV measuring area

\section{3. 計測および計算結果}

魚ロボットの尾びれ動作時において，PIV による計測および CFD による計算から得られた速度分布をそれぞれ図 2 (a),(b)に示文。また 代表速度 $U_{m}$ を差し引いた速度分布を図 3 に示す. 計算結果と計測結 果を比較すると，尾びれに近いところでは渦の位置や速度の大きさ がほぼ一致しているが，尾びれから離れると，尾びれによって押し 出される水の進行方向に違いが見られた，その理由としてCFDの計 算を 2 次元で行ったことや，魚口ボットの細部の動作までを正確に 再現できなかったことが考えられる. PIVによる計測結果では, 斜め にずれて放出される逆カルマン洞列が見られ，CFD による計算結果 では，魚ロボット後部方向に逆カルマン渦が交互に放出された，

尾びれの動作を停止させた時は，魚ロボット後部での流速は代 表速度 $148 \mathrm{~mm} / \mathrm{s}$ より遅くなった. それに対し, 尾びれ動作時には, 魚口ボット後部で代表速度の約 3 倍の流速が得られた。 また, CFD の計算結果をもとに得られた正味の推進力の時間挙動を図 4 に示 寸. 正味の推進力は, 魚ロボット頭部より $115 \mathrm{~mm}$ 上流の断面之, 尾びれ先端より $21 \mathrm{~mm}$ 下流の断面での水の運動量の変化から求 めた. 図より尾びれ運動による正味の推進力が半周期ごとに変化 していることが確かめられた。

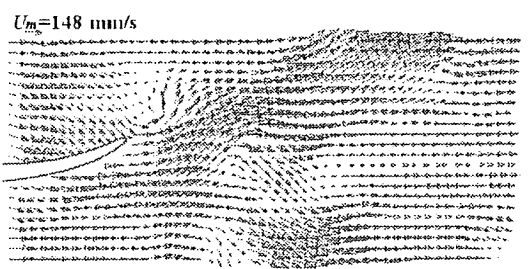

(a) PIV measurement

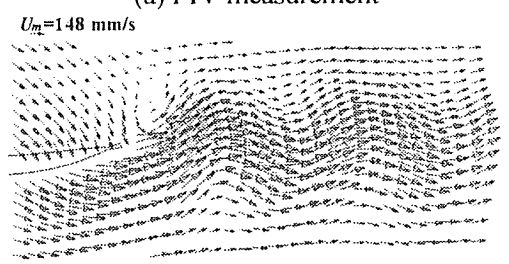

(b) Calculation

Fig.2 Velocity vectors obtained by PIV measurement and CFD calculation

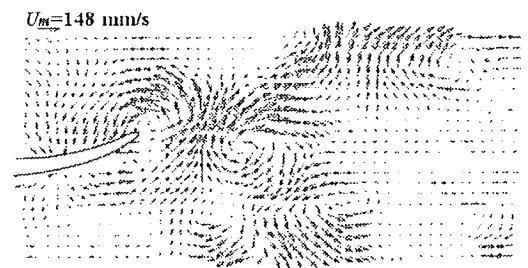

(a) PIV measurement

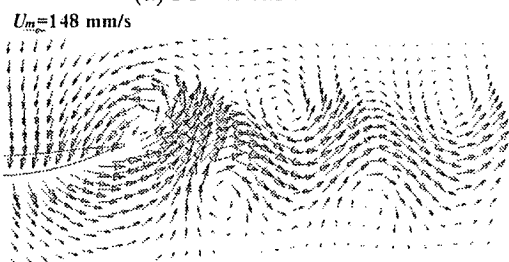

(b) Calculation

Fig.3 Velocity vectors subtracted $U_{m}$ from the velocity vectors obtained by PIV measurement and CFD calculation

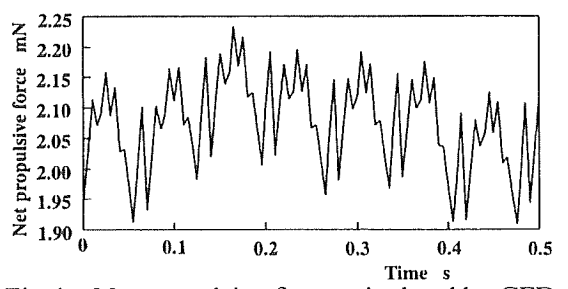

Fig.4 Net propulsive force calculated by CFD

\section{4. 結 言}

PIV およびCFDによって魚ロボットまわりの水の流動状態を調 尾びれ後部において逆カルマン渦列の発生を確喼することができう また，魚ロボットが，尾びれによって水を後方一押し出し，推進； を得ていることが確かめられた，今後，生きた魚を用いた PIV 実帮 と，同条件での3 次元 CFD 解析を試みる予定である.

\section{謝 辞}

本研究費の一部は, 科学研究費 (若手研究(B)17760209) の援 を受けた。ここに記して謝意を表す。

\section{参考文献}

(1) 脇坂 - 他 3 名, 機論(B)、59-559、(1993)，966. 